\title{
Tumor growth limited to subcutaneous site vs tumor growth in pulmonary site exhibit differential effects on systemic immunities
}

\author{
JUNKO MASUDA $^{1,2^{*}}$, EIJI TAKAYAMA $^{3 *}$, WARREN STROBER ${ }^{2}$, AYANO SATOH $^{1}$, YUJI MORIMOTO $^{4}$, \\ YASUKO HONJO $^{5}$, TATSUO ICHINOHE ${ }^{5}$, SHIN-ICHI TOKUNO ${ }^{6}$, TOSHIAKI ISHIZUKA ${ }^{7}$, TAKAHIRO NAKATA ${ }^{8}$, \\ AKIFUMI MIZUTANI ${ }^{1}$, NAOKI UMEMURA ${ }^{3}$, ATSUSHI KITANI ${ }^{2}$, IVAN J. FUSS $^{2}$, TSUKASA SHIGEHIRO $^{1}$, \\ HARUMI KAWAKI ${ }^{3}$, MASAKO MIZUNO-KAMIYA ${ }^{3}$, NOBUO KONDOH ${ }^{3}$ and MASAHARU SENO $^{1}$
}

${ }^{1}$ Division of Medical Bioengineering, Graduate School of Natural Science and Technology, Okayama University, Okayama, Japan; ${ }^{2}$ Mucosal Immunity Section, Laboratory of Host Defenses, National Institute of Allergy and Infectious Diseases, National Institutes of Health, Bethesda, MD, USA; ${ }^{3}$ Department of Oral Biochemistry, Asahi University School of Dentistry, Gifu; ${ }^{4}$ Department of Integrative Physiology and Bio-Nano Medicine, National Defense Medical College, Saitama;

${ }^{5}$ Department of Hematology and Oncology, Research Institute for Radiation Biology and Medicine, Hiroshima University, Hiroshima; ${ }^{6}$ Verbal Analysis of Pathophysiology, Graduate School of Medicine, The University of Tokyo, Tokyo;

${ }^{7}$ Department of Pharmacology, National Defense Medical College, Saitama; ${ }^{8}$ Department of Molecular and Cellular Anatomy, Faculty of Health Promotional Science, Tokoha University, Hamamatsu, Japan

Received February 13, 2017; Accepted May 8, 2017

DOI: 10.3892/or.2017.5646

\begin{abstract}
To evaluate systemic immunity associated with tumor growth limited to a subcutaneous site versus growth proceeding at multiple tumor sites, we established syngeneic mouse subcutaneous and pulmonary tumor models by local subcutaneous and intravenous injection of colon carcinoma CT26 cells. We found that splenic myeloid-derived suppressor cell (MDSC) levels were significantly increased in the subcutaneous tumor model but not in the pulmonary tumor model. Furthermore, both $\mathrm{CD} 4^{+}$and $\mathrm{CD} 8^{+} \mathrm{T}$ cells as well as $\mathrm{CD}^{+}{ }^{+} \mathrm{Foxp}^{+} \mathrm{T}$ cells were significantly decreased in the
\end{abstract}

Correspondence to: Dr Eiji Takayama, Department of Oral Biochemistry, Asahi University School of Dentistry, Hozumi 1851, Mizuho, Gifu 501-0296, Japan

E-mail: takayama@dent.asahi-u.ac.jp

*Contributed equally

Abbreviations: Abs, antibodies; CAFs, cancer-associated fibroblast cells; CT26 cells, colon carcinoma cells; DAMPs, damage-associated molecular patterns; ELISA, enzyme-linked immunosorbent assay; FBS, fetal bovine serum; FCM, flow cytometry; Foxp3, forkhead box transcription factor P3; IFN, interferon; IL, interleukin; IL-2R $\alpha$ chain, interleukin-2 receptor $\alpha$ chain; i.v., intravenously; MDSCs, myeloid derived suppressor cells; RPMI, Roswell Park Memorial Institute; RT, room temperature; SEM, standard error of the mean; s.c., subcutaneously; TILs, tumor-infiltrating lymphocytes; Th, helper T; TGF- $\beta$, transforming growth factor $\beta$; Tr1, type 1 regulatory $\mathrm{T}$ cells; Tregs, regulatory $\mathrm{T}$ cells

Key words: colon carcinoma, cytokine, myeloid-derived suppressor cell, regulatory $\mathrm{T}$ cells subcutaneous tumor model and were largely unchanged in the pulmonary tumor model. In addition, the subcutaneous model, but not the pulmonary model, displayed a Th1 polarization bias. This bias was characterized by decreased IL-4, IL-9, and IL-10 production, whereas the pulmonary model displayed increased production of IL-10. These results suggest that the mode of tumor development has differential effects on systemic immunity that may, in turn, influence approaches to treatment of cancer patients.

\section{Introduction}

Nests of tumor cells at primary and metastatic sites are usually infiltrated by a variety of cancer-associated fibroblasts (CAFs), endothelial cells, tumor-infiltrating lymphocytes (TILs), and macrophages, which collectively produce cytokines and other mediators that have the potential to modulate both local and systemic antitumor immune responses (1-4). These cells may include both myeloid-derived suppressor cells (MDSCs) and/or regulatory $\mathrm{T}$ cells (Tregs) (2-4), i.e., cells that suppress the proliferation of $\mathrm{CD} 4^{+}$helper $\mathrm{T}$ (Th) cells and antigen-specific $\mathrm{CD}^{+} \mathrm{T}$ cells (5), thus modifying antitumor responses by various distinct mechanisms (6,7). MDSCs form phenotypically heterogeneous groups of cells that share the capacity to exert a suppressor function $(8,9)$. The level of these cells increases in the presence of infection $(10,11)$ as well as in the presence of several types of murine $(4,11,12)$ and human cancers $(13-15)$. Conversely, Tregs comprise a subtype of Th-cells marked by the expression of high levels of the interleukin-2 receptor $\alpha$ chain (IL-2R $\alpha$-chain) (CD25) and forkhead box transcription factor P3 (Foxp3) (6,16-19). Treg levels have also been found to be increased in cancer patients (20). Despite both these types of cells exerting suppressive effects, at least at local tumor sites, they may have different effects on systemic immune responses. 
The lung is a major metastatic site for various kinds of cancer, including colorectal cancer. The environment of the pulmonary tumor is different from that of the solid primary tumor for lymphocytes and macrophages. For instance, unlike the hypoxic environment of solid tumors, tumors and TILs located in the lung occur in a well-oxygenated environment. $\mathrm{T}$ cell-intrinsic molecular function and proliferation is tightly controlled by oxygen tension (21). Moreover, effector T cell responses are regulated in the lung against innocuous foreign antigens. The mechanism by which the spread of the tumor to the lung influences systemic immunity remains unknown.

In the present study, we established a syngeneic mouse subcutaneous tumor model and experimental pulmonary tumor model, and found that these tumors had different effects on systemic immunity, as assessed in the spleen.

\section{Materials and methods}

Animals. Female 5-week-old BALB/c mice were obtained from Charles River Inc. (Kanagawa, Japan) and maintained under specific pathogen-free conditions at the Tsushima-kita Branch, Department of Animal Resources, Advanced Research Center, Okayama University. All animal experiments were reviewed and approved by the ethics committee for animal experiments of Okayama University under the ID OKU-2015229.

Monoclonal antibodies (mAbs). Anti-mouse CD3e (145-2C11) and CD11b (M1/70) mAbs were purchased from BD Biosciences (San Jose, CA, USA). Anti-mouse CD25 (PC61.5), CD16/ CD32 (93), and Gr-1 (RB6-8C5) mAbs were purchased from eBioscience (San Diego, CA, USA). Anti-mouse CD4 (RM4-5), CD8 $\alpha$ (53-6.7), and Foxp3 (3G3) mAbs were purchased from Tonbo Biosciences (San Diego, CA, USA).

Tumor cell cultures. The colon adenocarcinoma cell line, CT26 (N-nitro-N-methylurethane-induced tumor derived from BALB/c mouse), was purchased from the American Type Culture Collection (Rockville, MD, USA) and maintained in Roswell Park Memorial Institute (RPMI)-1640 medium (Sigma-Aldrich, St. Louis, MO, USA) supplemented with $10 \%(\mathrm{v} / \mathrm{v})$ heat-inactivated fetal bovine serum (FBS) (SAFC Biosciences, Lenexa, KS, USA) and 1\% (v/v) antibioticantimycotic solution $(10,000 \mathrm{U} / \mathrm{ml}$ penicillin, $10,000 \mu \mathrm{g} / \mathrm{ml}$ streptomycin, and $25 \mu \mathrm{g} / \mathrm{ml}$ amphotericin B; Life Technologies, Gaithersburg, MD, USA).

Tumor cell transplantations and histochemical analyses. CT26 cells $\left(5 \times 10^{5}\right.$ cells $/ 200 \mu \mathrm{l} /$ body $)$ were transplanted subcutaneously (s.c.) into the right flank, or intravenously (i.v.) into a female 6-week-old mouse. A sham mouse, as control experiments, was injected with saline alone. The mice were euthanized on day 14 after the transplantation. Tumor volumes were calculated as $1 / 2 \mathrm{x}$ length $\mathrm{x}$ width ${ }^{2}$. Tumors were analyzed histochemically, according to a previous study (21). Images were obtained using an Olympus (New York, NY, USA) LX81 at 20x and processed with MetaMorph software (Universal Imaging Corp., West Chester, PA, USA).

Splenocyte cultures and assays for cytokine levels. Splenocytes were isolated and cultured, according to a previous study (22).
Splenocytes $\left(4 \times 10^{5}\right.$ cells/well) were cultured for $48 \mathrm{~h}$ on flatbottom 96-well plates (Corning Costar, Cambridge, MA, USA) coated with $5 \mu \mathrm{g} / \mathrm{ml}$ anti-CD $3 \varepsilon \mathrm{mAb}$ in $200 \mu \mathrm{l} \mathrm{RPMI}-$ 1640 medium containing $50 \mu \mathrm{M} 2$-mercaptoethanol (Nacalai Tesque, Inc., Kyoto, Japan), and supplemented with $10 \%$ (v/v) FBS and $1 \%(\mathrm{v} / \mathrm{v})$ antibiotic-antimycotic solution. After cultivation, the produced IFN- $\gamma$, IL-4, IL-9, and IL-10 levels in culture supernatants were evaluated by cytokine-specific enzyme-linked immunosorbent assay (ELISA) commercially available from BD Biosciences and eBioscience.

Flow cytometry $(F C M)$. Splenocytes $\left(1 \times 10^{6}\right)$ were incubated with anti-CD16/CD32 $\mathrm{mAb}$ for $20 \mathrm{~min}$ on ice. Then, MDSCs were stained with anti-Gr-1 and CD11b mAbs. T cells were stained with anti-CD4, CD25, and CD8 mAbs for $30 \mathrm{~min}$ on ice, fixed with FACS lysing solution (BD Biosciences) for $10 \mathrm{~min}$ at room temperature (RT), permeabilized with FACS permeabilizing solution 2 (BD Biosciences) for $10 \mathrm{~min}$ at RT, and then stained with anti-Foxp3 $\mathrm{mAb}$ for $30 \mathrm{~min}$. The stained cells were analyzed by Accuri ${ }^{\mathrm{TM}}$ (BD Biosciences) and FlowJo Software (Treestar, Inc., San Carlos, CA, USA).

Statistical analyses. Survival curves were generated using the Kaplan-Meier method. Statistical analyses were performed using the Student's two-tailed t-test, the Mann-Whitney U, and the Pearson's correlation coefficient-tests. All analyses were performed using GraphPad Prism Software Version 6 (GraphPad Software Inc., San Diego, CA, USA). P-values $<0.05$ were considered statistically significant.

\section{Results}

Generation of murine models confined to subcutaneous and pulmonary sites. To explore the impact of subcutaneous and pulmonary tumors on systemic immunity with the same tumor cell line, we created murine tumor models in which tumor cells were confined to a single site at the subcutaneous site of injection or in which the tumor had undergone hematogenous spread to the lungs in the absence of growth at a subcutaneous site. To this end, we injected BALB/c mice with $5 \times 10^{5}$ CT26 cells (a colorectal cancer cell line) either s.c. or i.v., then examined these mice (or control mice injected with PBS) after injection to determine the course and extent of tumor spread. Mice administered CT26 cells by s.c. injection were alive at day 30 , whereas mice administered these cells by i.v. injection died between 14 and 16 days (Fig. 1A and B). We therefore euthanized and examined both s.c.- and i.v.-transplanted mice at day 14 after inoculation. The tumor volumes of the s.c.transplanted mice grew to $650-2,197 \mathrm{~mm}^{3}$ by day 14 , and were confined to the original site of injection (Fig. 1E). On the other hand, a large number of pulmonary nodules covered the lungs of i.v.-transplanted mice (Fig. 1D), and were present only in this organ (Fig. 1C and F).

After tumor inoculation, MDSCs are increased in s.c.transplanted mice, but not in i.v.-transplanted mice. Having established tumor models of tumors growing in only subcutaneous site or pulmonary site, we then examined regulatory cell development in the spleen in response to tumor growth. During the initial studies, we evaluated the level of accumulation of 

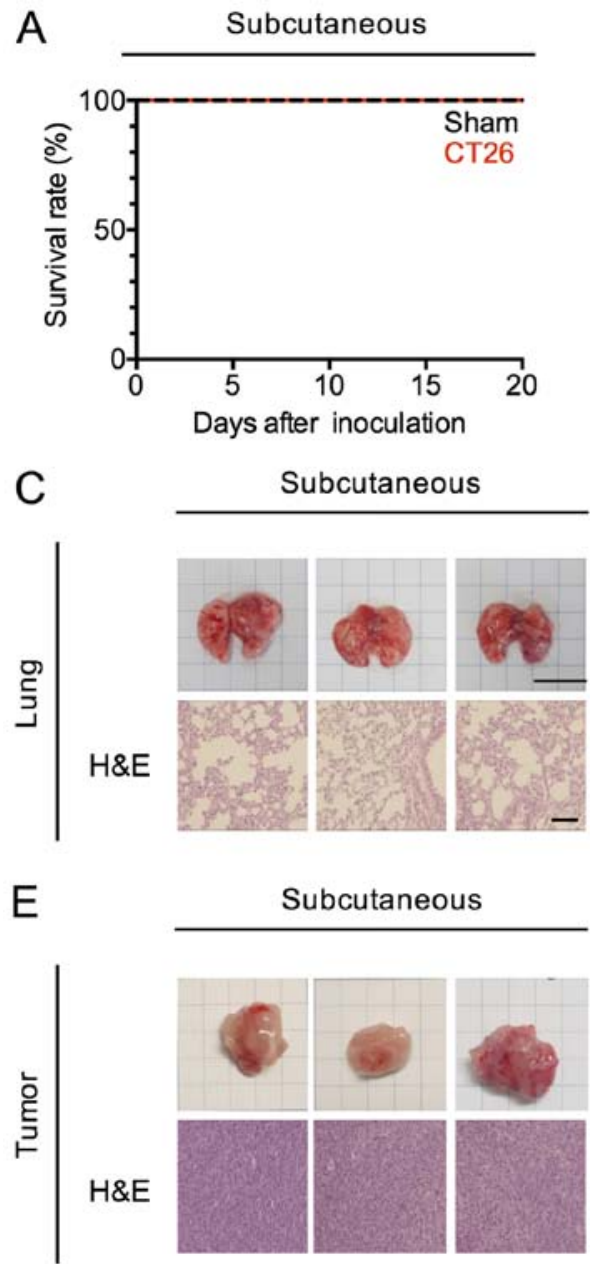
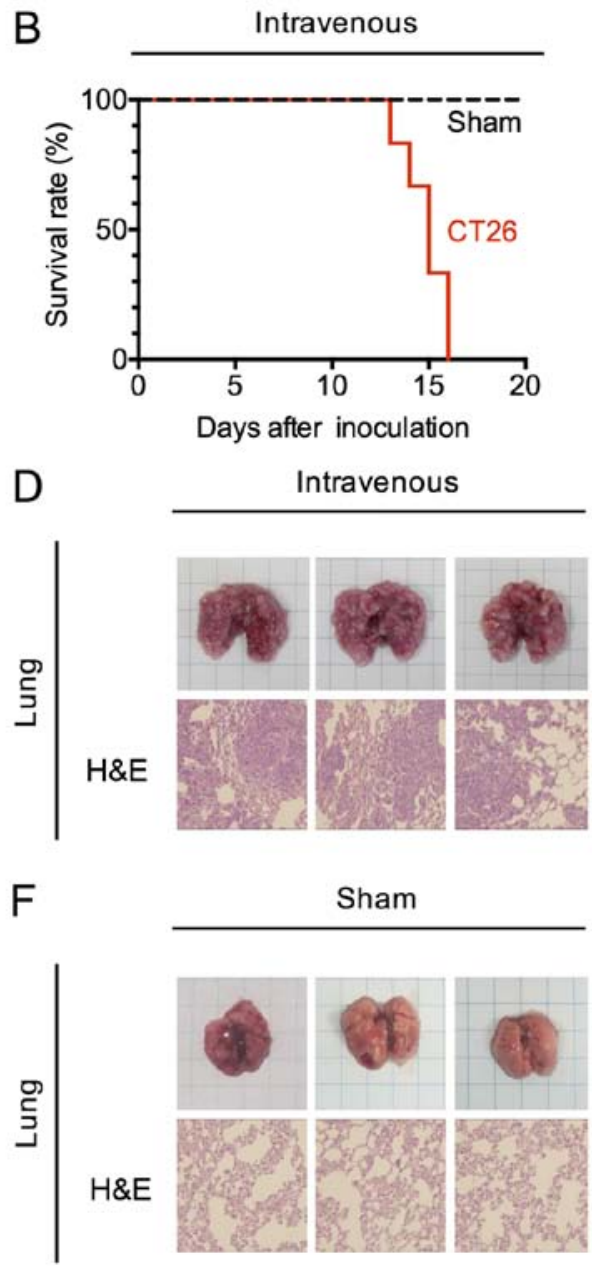

Figure 1. Murine carcinoma models confined to subcutaneous and pulmonary sites. (A and B) Kaplan-Meier survival curves of CT26-transplanted mice. CT26 cells $\left(5 \times 10^{5}\right.$ cells $/ 200 \mu \mathrm{l} /$ body) were transplanted subcutaneously (s.c.) into the right flank or intravenously (i.v.) of a female 6-week-old mouse. Data represent three pooled experiments; sham, $n=9$, and s.c., $n=9$ (A), and sham, $n=9$, and i.v., $n=9$ (B). (C-F) Hematoxylin/eosin (H\&E) staining of subcutaneous tumors and pulmonary tumor from the control (sham) and tumor-bearing (s.c. and i.v.) mice 14 days after CT26 transplantation. Engraftment, bar, 10 mm; H\&E staining, bar, $100 \mu \mathrm{m}$.

MDSCs in the spleens of mice comprising these two tumor models. These cells were identified by flow cytometry, taking advantage of their surface expression of either Gr- ${ }^{\text {hi }} \mathrm{CD} 11 \mathrm{~b}^{+}$ (mature myeloid cells) or $\mathrm{Gr}-1^{\mathrm{dim}} \mathrm{CD} 11 \mathrm{~b}^{+}$or $\mathrm{Gr}-1^{\text {intermediate }}$ $\mathrm{CD}_{11 b^{+}}$(immature myelomonocytic cells) $(8,23-25)$. It should be noted that the $\mathrm{T}$ cell suppressive capacities of $\mathrm{Gr}-1^{\mathrm{dim}}$ $\mathrm{CD}_{11 b^{+}}$MDSCs are higher than that of the Gr-1 ${ }^{\text {hi }} \mathrm{CD} 11 \mathrm{~b}^{+}$ MDSCs $(4,8,25)$; however, Gr- $1^{\text {hi }} \mathrm{CD} 11 \mathrm{~b}^{+}$MDSCs were shown to also acquire suppressor activities after lethal tuberculosis infection (10).

Gr- $1^{\text {hi }}$ CD $11 b^{+}$cells in the spleens of s.c.-transplanted mice were significantly increased (Fig. 2A) compared to PBS-injected mice (i.e., sham s.c.). In addition, Gr-1 ${ }^{\mathrm{dim}} \mathrm{CD} 11 \mathrm{~b}^{+}$ MDSCs were significantly increased (Fig. 2A). In contrast, no differences in the levels of either type of MDSCs were observed in i.v.-transplanted mice compared to sham-injected mice (Fig. 2B). These changes in the proportion of MDSCs in s.c.-transplanted and i.v.-transplanted mice were accompanied by corresponding changes in the total numbers of MDSCs (Fig. 2C and D). The data above clearly indicate that tumor cells existing at a subcutaneous site versus a pulmonary site have different effects on the systemic development of MDSCs; thus, these cells have the potential to regulate systemic $\mathrm{T}$ cell function.

T cell subsets in s.c.- and i.v.-transplanted CT26 tumor mice. We next turned our attention to levels (percentages) of T cells and $\mathrm{T}$ cell subsets in the spleens of the s.c.- and i.v.-transplanted mice. $\mathrm{CD}^{+} \mathrm{T}$ cells were significantly decreased in both s.c.- and i.v.-transplanted mice. In addition, $\mathrm{CD} 8^{+} \mathrm{T}$ cells were significantly decreased in s.c.-transplanted mice, whereas a non-significant change was observed in i.v.-transplanted mice (Fig. 3A and B). These proportion of $\mathrm{CD}^{+}$and $\mathrm{CD}^{+} \mathrm{T}$ cells in s.c.-transplanted mice were accompanied by corresponding changes in the total numbers of $\mathrm{CD}^{+}$and $\mathrm{CD}^{+} \mathrm{T}$ cells (Fig. 3C and E).

In s.c.-transplanted mice, the above decrease in levels of $\mathrm{CD}^{+} \mathrm{T}$ cells was accompanied by somewhat smaller, but significant decreases in the levels of $\mathrm{CD} 4^{+} \mathrm{CD} 25^{+} \mathrm{T}$ cells (Fig. 3A and D) as well as the subset of $\mathrm{CD} 25^{+} \mathrm{T}$ cells also expressing Foxp3 (Tregs) (Fig. 3A and G) compared to sham-inoculated mice $(18,26)$. In contrast, in i.v.-transplanted mice, the numbers of $\mathrm{CD} 4^{+} \mathrm{CD} 25^{+} \mathrm{T}$ cells and $\mathrm{CD} 4^{+} \mathrm{CD} 25^{+}$ Foxp $3^{+}$cells were similar compared to sham mice (Fig. 3B, 
A

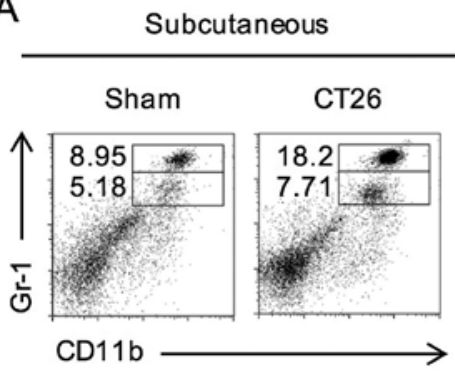

C

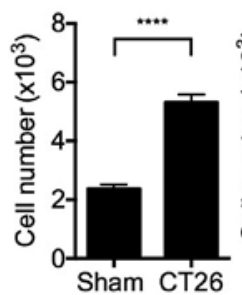

Gr-1 dim $\mathrm{CD} 11 b^{+}$

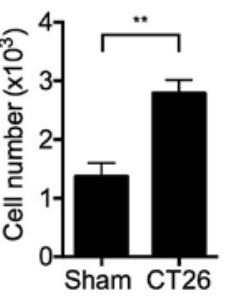

B

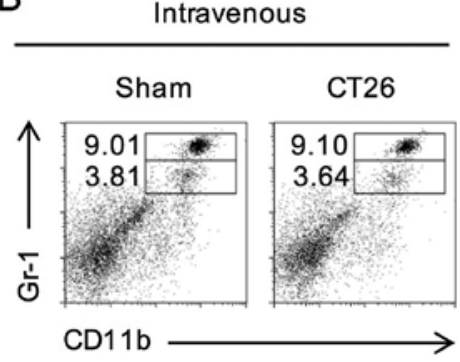

D $\mathrm{Gr}^{\mathrm{h}} \mathrm{h}^{\mathrm{C}} \mathrm{CD} 11 \mathrm{~b}^{+}$ Gr-1 ${ }^{\operatorname{dim}} \mathrm{CD} 11 \mathrm{~b}^{+}$
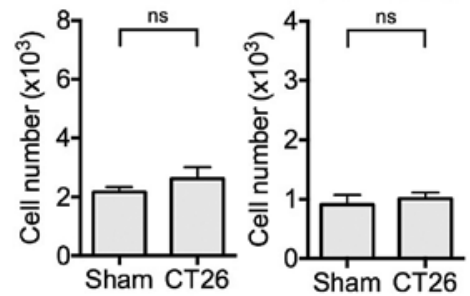

Figure 2. Splenic MDSC subsets in s.c.- and i.v.-transplanted CT26 tumor mice. At 14 days after subcutaneously (s.c.) into the right flank or intravenously (i.v.) transplantation, splenocytes from control (sham) or tumor-bearing s.c. and i.v. mice were isolated. MDSCs in splenocytes from mice bearing tumor were analyzed by FCM. (A and B) Representative dot plots of Gr- $1^{\text {hi }}$ CD11b ${ }^{+}$and $\mathrm{Gr}^{-1}{ }^{\mathrm{dim}} \mathrm{CD} 11 \mathrm{~b}^{+}$MDSC subsets. Numbers indicate percentages. (C and D) Cell numbers of $\mathrm{Gr}-1^{\mathrm{hi}}$ and Gr- ${ }^{\mathrm{dim}}$ MDSC subsets. The data are presented as the mean \pm SEM assessed by a Student's two-tailed t-test. ${ }^{* *}$ p $<0.01{ }^{*}{ }^{* * * *}$ p $<0.0001$; NS, not significant. $n=6 /$ group.

A

Subcutaneous

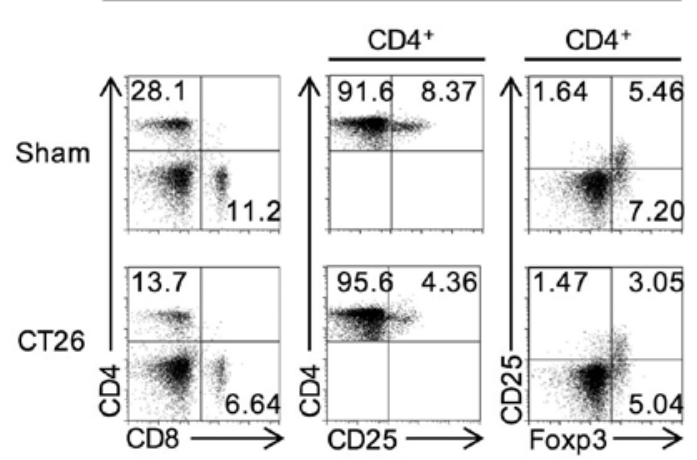

$\mathrm{C} \mathrm{CD}^{+}$
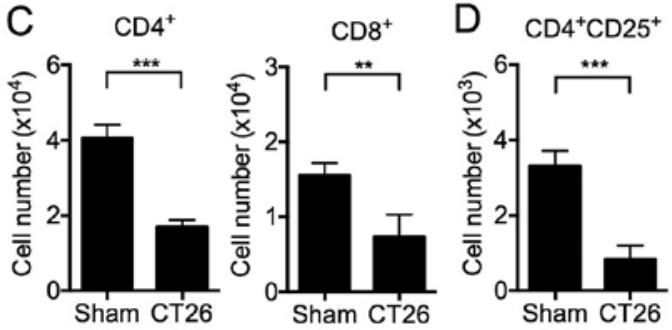

G

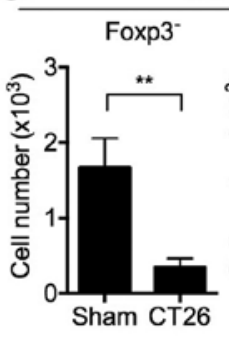

$\mathrm{CD}^{+} \mathrm{CD}^{2} 5^{+}$

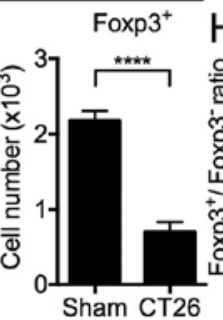

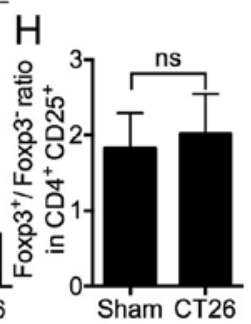

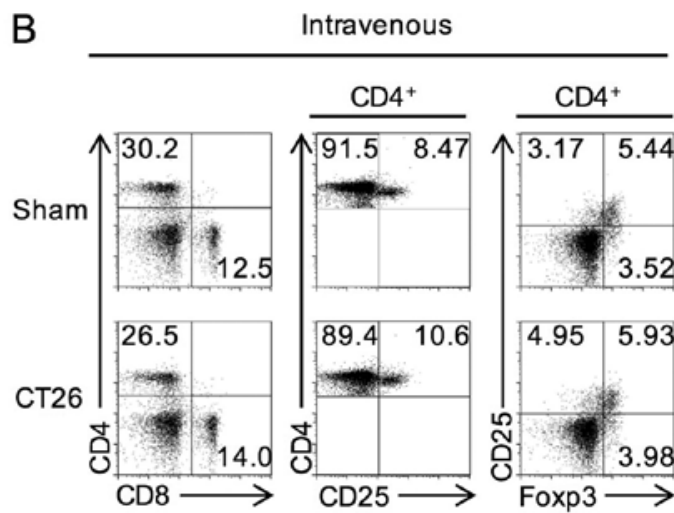

$\mathrm{E}$
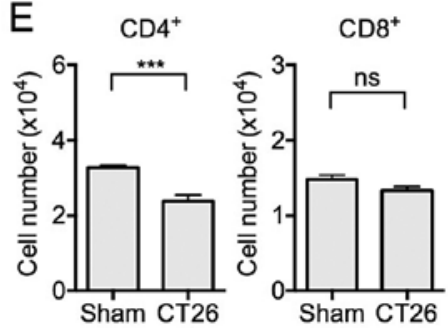

$\mathrm{F} \mathrm{CD}^{+} \mathrm{CD} 25^{+}$

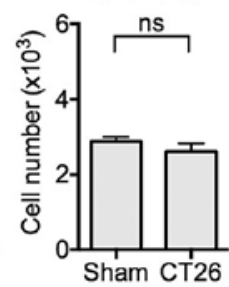

I

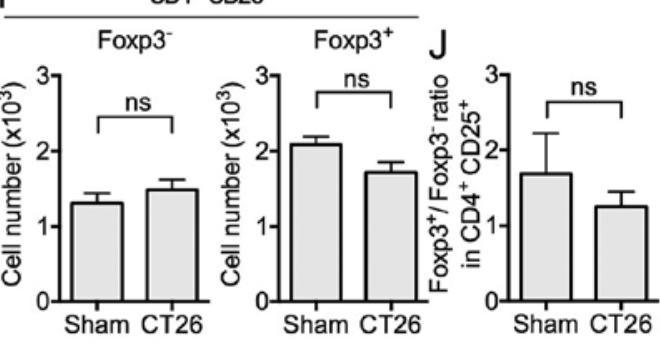

Figure 3. Splenic T cell subsets in s.c.- and i.v.-transplanted CT26 tumor mice. At 14 days after s.c. into the right flank or i.v. transplantation, splenocytes from control (sham) or tumor-bearing s.c. and i.v. mice were isolated. (A and B) Representative dot plot of $\mathrm{CD} 4^{+}, \mathrm{CD} 8^{+} \mathrm{CD} 4^{+} \mathrm{CD} 25^{+}$, and $\mathrm{CD} 4^{+} \mathrm{CD} 25^{+} \mathrm{Foxp} 3^{+}$in splenocytes analyzed by FCM. Numbers indicate percentages. (C and E) Cell number of CD4 and CD8 ${ }^{+}$. (D and F) Cell number of CD4 $4^{+} \mathrm{CD} 25^{+}$. (G and I) Cell number of Foxp3 $3^{-}$and Foxp3 $3^{+}$in $\mathrm{CD}^{+} \mathrm{CD} 25^{+}$. (H and J) Ratios of Foxp3 ${ }^{+}$and Foxp3 ${ }^{-}$in $\mathrm{CD}^{+} \mathrm{CD}^{2} 5^{+}$(Foxp3 $3^{+} / \mathrm{Foxp}^{-}$) were analyzed. The data are the mean \pm SEM assessed by a Student's two-tailed t-test. ${ }^{* *} \mathrm{p}<0.01 ;{ }^{* * *} \mathrm{p}<0.001 ;{ }^{* * * * *} \mathrm{p}<0.0001$; NS, not significant. $\mathrm{n}=6 /$ group. 


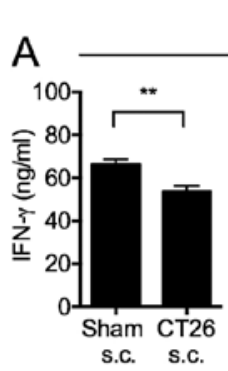

Subcutaneous

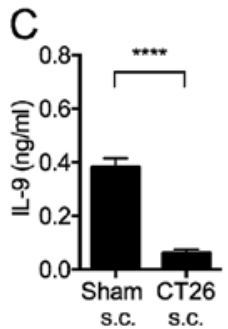

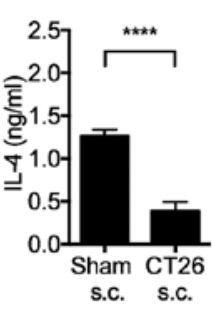
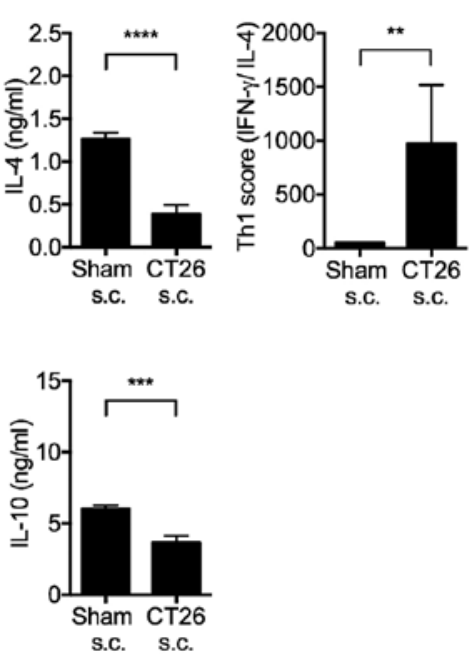

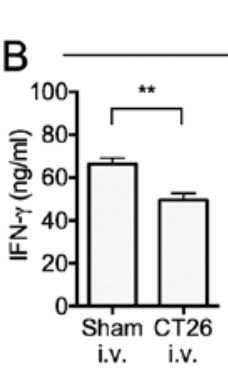

Intravenous

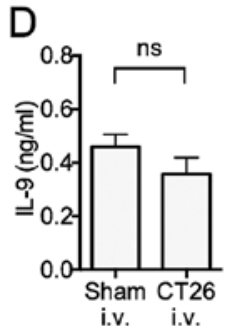

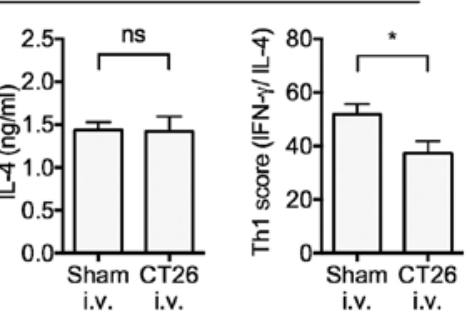

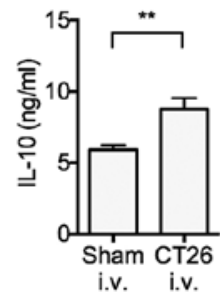

Figure 4. Cytokine productions by splenocytes in tumor-bearing mice. At 14 days after s.c. into the right flank, or i.v. transplantation, splenocytes from control (sham) or tumor inoculated s.c. and i.v. mice were isolated and stimulated with plate bound anti-CD3e mAb for 48 h, then harvested the culture supernatant. (A and B) Th1 (IFN- $\gamma$ ) and Th2 (IL-4) cytokine productions and Th1 score (IFN- $\gamma /$ IL-4) were analyzed. (C and D) IL-9 and IL-10 cytokine productions were analyzed. The data are presented as the mean \pm SEM assessed by a Student's two-tailed t-test and Mann-Whitney $\mathrm{U}$ test. * $\mathrm{p}<0.05$; ${ }^{* *} \mathrm{p}<0.01 ;{ }^{* * *} \mathrm{p}<0.001 ;{ }^{* * * *} \mathrm{p}<0.0001 ; \mathrm{NS}$, not significant. $\mathrm{n}=9$ /group.

F and I). The ratio of Foxp3 ${ }^{+}$to Foxp3 in $\mathrm{CD}^{+} \mathrm{CD}^{-} 5^{+}$cells was unchanged between the sham and s.c.-transplanted mice (Fig. 3H) and between the sham and i.v.-transplanted mice (Fig. 3J). Considered together, these results showed that whereas both s.c.- and i.v.-transplanted mice exhibit decreases in $\mathrm{CD}^{+} \mathrm{T}$ cell subsets, only in s.c.-transplanted mice is this decrease also reflected in a decrease in regulatory $\mathrm{CD} 4^{+}$ $\mathrm{CD} 25^{+} \mathrm{Foxp}^{+} \mathrm{T}$ cells. In addition, these results showed that an increase in MDSCs in the s.c.-transplanted mice is associated with a decrease in Foxp $3^{+}$Tregs, and the lack of increase in MDSCs in the i.v.-transplanted mice is not associated with a change in Foxp3 ${ }^{+}$Tregs.

IFN- $\gamma$ and IL-4 cytokine production by splenocytes in tumorbearing mice. Given the different regulatory cell responses of s.c.- and i.v.-transplanted tumor-bearing mice, we examined cytokine responses of splenocytes in the mice. We determined Th1 responses (i.e., IFN- $\gamma$ production) and Th2 responses (i.e., IL-4 production) by anti-CD $3 \varepsilon$ Ab to stimulate $\mathrm{T}$ cells in splenocytes in the two groups of mice.

The IFN- $\gamma$ production from whole splenocytes stimulated with immobilized anti-CD3e antibody (Ab) was significantly decreased in both s.c.- and i.v.-transplanted mice (Fig. 4A and $\mathrm{B}$ ). In contrast, IL-4 production was significantly decreased in s.c.-transplanted mice (Fig. 4A), but not in i.v.-transplanted mice (Fig. 4B). These changes were reflected in the Th1 score (i.e., ratio of IFN- $\gamma$ to IL- 4 production) that was significantly increased in s.c.-transplanted mice (Fig. 4A), and decreased in i.v.-transplanted mice (Fig. 4B). These results indicated that s.c.-transplanted mice exhibit increased Th1 polarization, whereas i.v.-transplanted mice exhibited marginally decreased Th1 polarization.

$I L-10$ and $I L-9$ cytokine production from splenocytes in tumor-bearing mice. In further cytokine studies of s.c.- and i.v.-transplanted mice, we measured splenocyte production of IL-10 and IL-9 following anti-CD3e stimulation. IL-10 is an anti-inflammatory cytokine with diverse effects on most hematopoietic cell types, and inhibits activation and effector function of T cells, monocytes, and macrophages $(27,28)$. IL-10 is produced mainly by Th $2 \mathrm{~T}$ cells, although it can also be produced by Th1 $\mathrm{T}$ cells under certain conditions.

In addition, IL-10 can be produced by other types of T cells such as Tregs, Typel regulatory T cells (Tr1), Th9 cells, as well as by non-T cells such as MDSCs $(6,18,26-28)$. On the other hand, IL-9 is clearly a Th2 cytokine as its synthesis is induced by IL- 4 and transforming growth factor $\beta$ (TGF- $\beta$ ) (29).

IL-9 production was significantly decreased in s.c.-transplanted mice, but unchanged in i.v.-transplanted mice (Fig. 4C and D). Similarly, IL-10 production from whole splenocytes stimulated with immobilized anti-CD $3 \varepsilon$ Ab was significantly decreased in s.c.-transplanted mice, but significantly increased in i.v.-transplanted mice (Fig. 4C and D). These results are again consistent with the view that s.c.-transplanted mice exhibit increased Th1 polarization, whereas i.v.-transplanted mice exhibit marginally decreased Th1 polarization.

\section{Discussion}

In the present study, we created mouse models of tumor development, i.e., mice in which tumor cells (CT26 cells) were limited to the site of injection and did not display metastatic behavior (s.c.-transplanted mice) and mice in which tumor cells were immediately subjected to hematogenous dissemination and developed at multiple sites in the lung (i.v.transplanted mice). A striking difference in the immunologic response to the two modes of tumor development in these models was that a tumor limited to a subcutaneous site led to the appearance of increased numbers of both $\mathrm{Gr}-\mathrm{1}^{\text {hi }} \mathrm{CD} 1 \mathrm{~b}^{+}$ and $\mathrm{Gr}-1^{\mathrm{dim}} \mathrm{CD} 11 \mathrm{~b}^{+}$MDSCs in the spleen, whereas a pulmonary tumor exhibited no such increase. At the same time, these two modes of tumor development had an inverse effect 
on $\mathrm{CD}^{+}{ }^{+} \mathrm{CD} 25^{+}$Foxp3 $^{+}$Tregs in the spleen in that a tumor limited to a subcutaneous site exhibited decreased numbers of Tregs, whereas a pulmonary tumor exhibited no change in numbers of such cells. Current notions of MDSC development suggest that the accumulation of tumor cells create a milieu in which damage-associated molecular patterns (DAMPs) and other tumor-derived inflammatory factors induce effector cell production of a host of inflammatory factors. These factors collectively induce development of MDSCs and presumably their dissemination to distant lymphoid sites such as the spleen (30). The studies conducted here suggest that a tumor milieu capable of MDSC induction occurs at subcutaneous sites of development, but not at pulmonary site. Thus, by their differential effects on the development and dissemination of potentially suppressive MDSCs, subcutaneous tumor development and pulmonary tumor development might have very different effects on systemic host immunity.

A second difference in the systemic regulatory cell response between a tumor limited to subcutaneous site of development and a pulmonary tumor in the models studied here was that splenic $\mathrm{CD}^{+} \mathrm{CD} 25^{+}$Foxp $3^{+}$Treg levels were decreased in mice with the tumor limited to subcutaneous site, whereas no change in the levels of these cells was observed in mice with pulmonary tumor. This finding is somewhat unexpected, given that MDSCs have been shown to induce Tregs, possibly via their production of TGF- $\beta$ and IL-10 (2). Thus, one would expect that increased splenic MDSC levels would be accompanied by increased Treg levels. One possible explanation of this unexpected finding is that MDSCs have a direct suppressive effect on Treg development via the production of arginase $\mathrm{I}$, a factor that mediates $\mathrm{T}$ cell starvation and inhibition of $\mathrm{T}$ cell proliferation of all $\mathrm{T}$ cells, including Tregs $(15,20,23)$. This possibility is consistent with our finding that mice with increased MDSC levels in the spleen exhibit decreases in all T cells, including $\mathrm{CD} 4^{+} \mathrm{CD} 25^{+}$Foxp3- $\mathrm{T}$ cells, with the latter representing activated $\mathrm{T}$ cells that are not Tregs. In addition, it is consistent with our findings that there is an inverse correlation between MDSC levels and $\mathrm{CD} 4^{+} \mathrm{CD} 25^{+}$ Foxp3 $3^{+} \mathrm{T}$ cells.

Before a spontaneous metastasis event, primary tumor cells convert gene expression pattern to lose adhesion and migration (31). Since we transplanted same tumor cells, the two tumor growth models established do not reflect primary tumors and metastatic tumors. Nevertheless, many studies have shown anti-inflammatory Th2 shift in breast, gastric and non-small cell lung cancer patients (32-35), and advanced cancer patients (36) with related cytokine production. In addition, IL-10 levels that strongly correlate with clinical stage and poor prognosis were elevated (37-40). Thus, our pulmonary tumor model that also induced Th2 shift and increase of IL-10 levels might partly be the same as stage IV patients. On the other hand, the change of systemic immunity in this model might possibly be caused by pulmonary embolism rather than pulmonary tumor. Further studies are needed to compare the change of systemic immunity in the pulmonary tumor model with spontaneous metastasis model.

The pleiotropic cytokine IL-9 is produced by Th cells and originally associated with the Th2 phenotype (41). IL-9 has been reported to have both a pro-inflammatory and immunosuppressive function (42). However, IL-9 levels and function in cancer remain poorly understood. Although the study of tumor-bearing mice with IL-9 neutralizing antibodies showed antitumor immune responses (42), we found that the splenic IL-9 levels, especially in subcutaneous tumor, were significantly lower than in the sham control (Fig. 4C), which is consistent with the observation in colon cancer patients (43). Thus, IL-9 might not proactively function in systemic immunities of cancer patients.

In conclusion, we established mouse models that clearly recognize the differences between subcutaneous tumors and pulmonary tumors. As these mouse models are able to represent well systemic immunity in cancer patients, they might be useful for exploitation of immunotherapy along with cancer progression.

\section{Acknowledgements}

This study was supported in part by Program to Disseminate Tenure Tracking System, MEXT, Japan, by Okayama Foundation for Science and Technology, by Ryobi Teien Memory Foundation, by Sanyo Hohso Foundation, by the Grants-in-Aid for Scientific Research from the Japan Society for the Promotion of Science (15K11096 and 15H03002), and by the Program of the Network-Type Joint Usage/Research Disaster Medical Science of Hiroshima University, Nagasaki University, and Fukushima Medical University.

\section{References}

1. Liu Y, O'Leary CE, Wang LS, Bhatti TR, Dai N, Kapoor V, Liu P, Mei J, Guo L, Oliver PM, et al: CD11b ${ }^{+}$Ly $6 \mathrm{G}^{+}$cells inhibit tumor growth by suppressing IL-17 production at early stages of tumorigenesis. OncoImmunology 5: e1061175, 2015.

2. Ostrand-Rosenberg S and Sinha P: Myeloid-derived suppressor cells: Linking inflammation and cancer. J Immunol 182: 4499-4506, 2009.

3. Mougiakakos D, Choudhury A, Lladser A, Kiessling R and Johansson CC: Regulatory T cells in cancer. Adv Cancer Res 107: 57-117, 2010.

4. Fichtner-Feigl S, Terabe M, Kitani A, Young CA, Fuss I, Geissler EK, Schlitt HJ, Berzofsky JA and Strober W: Restoration of tumor immunosurveillance via targeting of interleukin-13 receptor-alpha 2. Cancer Res 68: 3467-3475, 2008.

5. Nagaraj S, Schrum AG, Cho H-I, Celis E and Gabrilovich DI: Mechanism of $\mathrm{T}$ cell tolerance induced by myeloid-derived suppressor cells. J Immunol 184: 3106-3116, 2010.

6. Alhamarneh O, Agada F, Madden L, Stafford N and Greenman J: Serum IL10 and circulating CD4(+) CD25(high) regulatory $\mathrm{T}$ cell numbers as predictors of clinical outcome and survival in patients with head and neck squamous cell carcinoma. Head Neck 33: 415-423, 2011.

7. Shevach EM: Regulatory T cells in autoimmmunity. Annu Rev Immunol 18: 423-449, 2000.

8. Chen S, Akbar SMF, Abe M, Hiasa Y and Onji M: Immunosuppressive functions of hepatic myeloid-derived suppressor cells of normal mice and in a murine model of chronic hepatitis B virus. Clin Exp Immunol 166: 134-142, 2011.

9. Yu J, Du W, Yan F, Wang Y, Li H, Cao S, Yu W, Shen C, Liu J and Ren X: Myeloid-derived suppressor cells suppress antitumor immune responses through IDO expression and correlate with lymph node metastasis in patients with breast cancer. J Immunol 190: 3783-3797, 2013.

10. Tsiganov EN, Verbina EM, Radaeva TV, Sosunov VV, Kosmiadi GA, Nikitina IY and Lyadova IV: Gr- ${ }^{\mathrm{dim}} \mathrm{CD} 11 \mathrm{~b}^{+}$ immature myeloid-derived suppressor cells but not neutrophils are markers of lethal tuberculosis infection in mice. J Immunol 192: 4718-4727, 2014.

11. Youn J-I, Nagaraj S, Collazo M and Gabrilovich DI: Subsets of myeloid-derived suppressor cells in tumor-bearing mice. J Immunol 181: 5791-5802, 2008. 
12. Rutkowski MR, Stephen TL, Svoronos N, Allegrezza MJ, Tesone AJ, Perales-Puchalt A, Brencicova E, Escovar-Fadul X, Nguyen JM, Cadungog MG, et al: Microbially driven TLR5dependent signaling governs distal malignant progression through tumor-promoting inflammation. Cancer Cell 27: 27-40, 2015.

13. Wang JC, Kundra A, Andrei M, Baptiste S, Chen C, Wong C and Sindhu H: Myeloid-derived suppressor cells in patients with myeloproliferative neoplasm. Leuk Res 43: 39-43, 2016.

14. Stiff A, Trikha P, Wesolowski R, Kendra K, Hsu V, Uppati S, McMichael E, Duggan M, Campbell A, Keller K, et al: Myeloidderived suppressor cells express Bruton's tyrosine kinase and can be depleted in tumor-bearing hosts by ibrutinib treatment. Cancer Res 76: 2125-2136, 2016.

15. Highfill SL, Rodriguez PC, Zhou Q, Goetz CA, Koehn BH, Veenstra R, Taylor PA, Panoskaltsis-Mortari A, Serody JS, Munn DH, et al: Bone marrow myeloid-derived suppressor cells (MDSCs) inhibit graft-versus-host disease (GVHD) via an arginase-1-dependent mechanism that is up-regulated by interleukin-13. Blood 116: 5738-5747, 2010.

16. Pesu M, Watford WT, Wei L, Xu L, Fuss I, Strober W, Andersson J, Shevach EM, Quezado M, Bouladoux N, et al: T-cell-expressed proprotein convertase furin is essential for maintenance of peripheral immune tolerance. Nature 455: 246-250, 2008.

17. Xu L, Kitani A, Stuelten C, McGrady G, Fuss I and Strober W: Positive and negative transcriptional regulation of the Foxp3 gene is mediated by access and binding of the Smad3 protein to enhancer I. Immunity 33: 313-325, 2010.

18. Alhamarneh O, Amarnath SMP, Stafford ND and Greenman J: Regulatory T cells: What role do they play in antitumor immunity in patients with head and neck cancer? Head Neck 30: 251-261, 2008.

19. Liu Y, Zhang P, Li J, Kulkarni AB, Perruche S and Chen W: A critical function for TGF-beta signaling in the development of natural $\mathrm{CD} 4^{+} \mathrm{CD} 25^{+} \mathrm{Foxp}^{+}$regulatory T cells. Nat Immunol 9: 632-640, 2008

20. Gabitass RF, Annels NE, Stocken DD, Pandha HA and Middleton GW: Elevated myeloid-derived suppressor cells in pancreatic, esophageal and gastric cancer are an independent prognostic factor and are associated with significant elevation of the Th2 cytokine interleukin-13. Cancer Immunol Immunother 60: 1419-1430, 2011

21. Yamazaki T, Masuda J, Omori T, Usui R, Akiyama H and Maru Y: EphA1 interacts with integrin-linked kinase and regulates cell morphology and motility. J Cell Sci 122: 243-255, 2009.

22. Takayama E, Seki S, Ohkawa T, Ami K, Habu Y, Yamaguchi T, Tadakuma $\mathrm{T}$ and Hiraide $\mathrm{H}$ : Mouse $\mathrm{CD} 8^{+} \mathrm{CD} 122^{+} \mathrm{T}$ cells with intermediate TCR increasing with age provide a source of early IFN-gamma production. J Immunol 164: 5652-5658, 2000

23. Gabrilovich DI and Nagaraj S: Myeloid-derived suppressor cells as regulators of the immune system. Nat Rev Immunol 9: $162-174,2009$.

24. Terabe M, Matsui S, Park J-M, Mamura M, Noben-Trauth N, Donaldson DD, Chen W, Wahl SM, Ledbetter S, Pratt B, et al: Transforming growth factor-beta production and myeloid cells are an effector mechanism through which CD1d-restricted $\mathrm{T}$ cells block cytotoxic $\mathrm{T}$ lymphocyte-mediated tumor immunosurveillance: Abrogation prevents tumor recurrence. J Exp Med 198: 1741-1752, 2003

25. Holmgaard RB, Zamarin D, Li Y, Gasmi B, Munn DH, Allison JP, Merghoub T and Wolchok JD: Tumor-expressed IDO recruits and activates MDSCs in a Treg-dependent manner. Cell Rep 13: $412-424,2015$
26. Yao Y, Vent-Schmidt J, McGeough MD, Wong M, Hoffman HM, Steiner TS and Levings MK: Trl cells, but not Foxp $3^{+}$regulatory T cells, suppress NLRP3 inflammasome activation via an IL-10dependent mechanism. J Immunol 195: 488-497, 2015.

27. Redford PS, Murray PJ and O'Garra A: The role of IL-10 in immune regulation during $M$. tuberculosis infection. Mucosal Immunol 4: 261-270, 2011.

28. Saraiva M and O'Garra A: The regulation of IL-10 production by immune cells. Nat Rev Immunol 10: 170-181, 2010.

29. Beriou G, Bradshaw EM, Lozano E, Costantino CM, Hastings WD, Orban T, Elyaman W, Khoury SJ, Kuchroo VK, Baecher-Allan C, et al: TGF-beta induces IL-9 production from human Th17 cells. J Immunol 185: 46-54, 2010.

30. Zhao Y, Wu T, Shao S, Shi B and Zhao Y: Phenotype, development, and biological function of myeloid-derived suppressor cells. OncoImmunology 5: e1004983, 2015.

31. Heerboth S, Housman G, Leary M, Longacre M, Byler S, Lapinska K, Willbanks A and Sarkar S: EMT and tumor metastasis. Clin Transl Med 4: 6, 2015.

32. Li J, Wang Z, Mao K and Guo X: Clinical significance of serum T helper $1 / \mathrm{T}$ helper 2 cytokine shift in patients with non-small cell lung cancer. Oncol Lett 8: 1682-1686, 2014.

33. Hong C-C, Yao S, McCann SE, Dolnick RY, Wallace PK, Gong Z, Quan L, Lee KP, Evans SS, Repasky EA, et al: Pretreatment levels of circulating Th1 and Th2 cytokines, and their ratios, are associated with ER-negative and triple negative breast cancers. Breast Cancer Res Treat 139: 477-488, 2013.

34. Liang J, Li Y, Liu X, Xu X and Zhao Y: Relationship between cytokine levels and clinical classification of gastric cancer. Asian Pac J Cancer Prev 12: 1803-1806, 2011.

35. Seledtsov VI, Goncharov AG and Seledtsova GV: Clinically feasible approaches to potentiating cancer cell-based immunotherapies. Hum Vaccin Immunother 11: 851-869, 2015.

36. Sato M, Goto S, Kaneko R, Ito M, Sato S and Takeuchi S: Impaired production of Th1 cytokines and increased frequency of Th2 subsets in PBMC from advanced cancer patients. Anticancer Res 18D: 3951-3955, 1998.

37. Szaflarska A, Szczepanik A, Siedlar M, Czupryna A, Sierzega M, Popiela T and Zembala M: Preoperative plasma level of IL-10 but not of proinflammatory cytokines is an independent prognostic factor in patients with gastric cancer. Anticancer Res 29: 5005-5012, 2009.

38. Kozłowski L, Zakrzewska I, Tokajuk P and Wojtukiewicz MZ: Concentration of interleukin-6 (IL-6), interleukin-8 (IL-8) and interleukin-10 (IL-10) in blood serum of breast cancer patients. Rocz Akad Med Bialymst 48: 82-84, 2003.

39. Asadullah K, Sterry W and Volk HD: Interleukin-10 therapy review of a new approach. Pharmacol Rev 55: 241-269, 2003.

40. Habu Y, Seki S, Takayama E, Ohkawa T, Koike Y, Ami K, Majima T and Hiraide H: The mechanism of a defective IFN- $\gamma$ response to bacterial toxins in an atopic dermatitis model, $\mathrm{NC} / \mathrm{Nga}$ mice, and the therapeutic effect of IFN- $\gamma$, IL-12, or IL-18 on dermatitis. J Immunol 166: 5439-5447, 2001.

41. Noelle RJ and Nowak EC: Cellular sources and immune functions of interleukin-9. Nat Rev Immunol 10: 683-687, 2010.

42. Lu Y, Hong S, Li H, Park J, Hong B, Wang L, Zheng Y, Liu Z, $\mathrm{Xu}$ J, He J, et al: Th9 cells promote antitumor immune responses in vivo. J Clin Invest 122: 4160-4171, 2012.

43. Huang Y, Cao Y, Zhang S and Gao F: Association between low expression levels of interleukin-9 and colon cancer progression. Exp Ther Med 10: 942-946, 2015. 